\title{
Social Acceptance of the Integrated Students in Regular Elementary School
}

\section{Eva Lörinczová}

\begin{abstract}
The integration of the students in the school is accompanied by a number of problems, not only with academic success rate of the individual, but also with his inclusion in the team of peers. A minor part of the issue is dealing with the social dimension of the educational process. The contribution is therefore oriented towards the acceptance of the individual, which we examined in the domain of the integrated 398 adolescents regular elementary school. Through the Questionnaire on social acceptance (Juhas, 1990), we measured the degree of acceptance of individuals, their view of the team, the emotional, families and school classes experiencing relationship and relationship to classmates. We found significant differences in the view of the individual to the team class and Emotional survival of the individual in a school class considering to integrated and intact students. These results suggest a subjective view of the individual to the collective of peers. As well, this can be attributed to the small development of social skills integrated individuals, as it indicates the detected a statistically significant difference in the emotional experiences of the individual.
\end{abstract}

Key words: emotional survival, integration, collective classes, social acceptance. 


\title{
Sociálna akceptácia integrovaných žiakov v bežnej základnej škole
}

\begin{abstract}
Abstrakt
Integrácia žiaka do bežnej školy je sprevádzaná viacerými problémami, ktoré nesúvisia len s akademickou úspešnostou jednotlivca, ale aj s jeho sociálnym začlenením do kolektívu rovesníkov. Menšia čast' tejto problematiky sa zaoberá sociálnou dimenziou výchovno-vzdelávacieho procesu. Príspevok sa preto orientuje na doménu akceptácie integrovaného jednotlivca, čo sme skúmali na 398 adolescentoch bežnej základnej školy. Prostredníctvom Dotazníka sociálnej akceptácie (Juhás, 1990) sme zistovali mieru akceptácie jednotlivcov, ich pohlad na kolektív triedy, emocionálne prežívanie, vzt’ah rodiny a školy a vztah k spolužiakom. Signifikantné rozdiely sme zistili v premenných Pohl'ad jednotlivca na kolektív školy a Emocionálne prežívanie jednotlivca v školskej triede vzhladom na integrovaných a intaktných respondentov. Takéto výsledky naznačujú subjektívny pohlad jednotlivca na kolektív rovesníkov. Rovnako, to môže priamo súvisiet’ s malým rozvojom sociálnych zručností integrovaných jednotlivcov, tak ako to naznačuje zistený štatisticky významný rozdiel v emocionálnom prežívaní jednotlivca.
\end{abstract}

Klúčové slová: emocionálne prežívanie, integrácia, kolektív triedy, sociálna akceptácia.

\section{Introduction}

A number of parents and experts agree that the current school is the best choice for individuals with special needs. The biggest advantages of the do not speak of only the academic benefits, but also the positive benefits of socialization (Frederickson, Dunsmuir, Lang \& Monsena, 2004). Those associated with the opportunity to develop positive relationships with their peers and individual to integrate into the social life (Scheepstra, Nakken \& Pijl, 1999). On the other hand, international studies have repeatedly shown, that the inclusion of students with special needs does not lead automatically to increase friendship between these individuals and their peers (Buysse, Davis Goldman \& Skinner, 2002; Guralnick, Neville, Hammond \& Connor, 2007; Pavri \& Luftig, 2000). Therefore, the fundamental question and the problem is social acceptance of an integrated individual in the regular class, to what extent has created social relationships between peers, as perceived by an individual, and last but not least the integrated classes for his emotional survival in the collective of their peers. 


\section{Socialization of students with special needs}

In the link to a small social group, class, stresses in particular the relationship component of social system made up of three categories: personality - interaction - sociall environment. In the school environment, individuals need to understand that others have unique characteristics, which differ from each other. They also need to understand that the others separately think, feel and know different things. However, such information can only be obtained in its social context or environment, which are to be regarded as a necessary condition to man as a biological creature to become social beings, capable of interpersonal communication. Social group affects to a large extent attitudes, judgements, opinions and attitudes of other individuals, peers and teachers themselves. Therefore, the main advantages of an inclusive education include the heterogeneity of the learning environment. Lechta (2010) is of the opinion that this diversity is very important from the point of view, but also in terms of developing transdidactics intact individuals. On the other hand, it may also become a risk environment, and not only in terms of educational success of individuals with special needs, but also in terms of the development of the intact individuals.

On the second level of elementary schools is important for individuals to be part of the community, were somewhere, and had been the favourite friends, because in the period between the ages of 13 to 15 years of rising need for friendship and intimacy, which is confirmed by Čerešník \& Dolejš (2015), who reported that during this period, individuals are more inclined to frends group. During the last stage of the basic walking to school are individuals in the period of adolescence, where physiological changes that produce changes in the emotional and social stage. Period of adolescent is characterized by a number of changes, but we focus on the individual crisis, in which the personality is characterised by internal tendencies, and lack of conflicts externally. It is also known that an individual going through different social roles, which are associated with certain standards and values and often interacts with the other members of the group, where he creates new social roles, thus shaping their social awareness, creating a troupe in the collective impact of group classes and override the influence of adults, including the rovesníckej starts with the parents. Therefore, the school environment represents the best form of the creation of new relationships and friendships. On the other hand, it can lead to social exclusion in the school environment in a complete isolation in social life. The lack of social contact with friends, the low rate of control of social skills and negative sebapoňatie leading to problems that may occur up to aggressive behaviour, social anxiety, and in some studies with depression (Jordan, 2013; Suchá \& Dolejš, 2016) and stress. Fry (1998) considered to be the core of these factors, interpersonal relations, which create an atmosphere of trust and acceptance. In may a young man to experience and express their doubts and insecurities, can get the courage to search and examine the values and objectives that it can provide meaningful, fulfill- 
ing, and which are not. Langmeier \& Krejčírová $(1998,156)$ state that: "...in this period, the young people have a tendency to be assessed, in particular, by the reactions of others to themselves and pursuant to what they themselves think about how others see them."

In the link to the issue of an integrated individual referred to the sentence they receive more importance. For example, research Guralnicka, Neville \& Hammond et al. (2007) describes how friendships play a central role in relations, as to a large extent affect the mutual relations and provide the complex development of the personality of the individual. Friendships formed during early childhood and school age constitute a valuable context for learning social skills that are necessary for the social, communicative and emotional development of the individual. To social inclusion occurs if every person in your individuality by accepted and has the opportunity to fully participate in it (Anderliková, 2013). Differences and deviations are taken in the context of social inclusion as enrichment for the Group and the company, or does not, or not (maybe rarely) for an exception. The right to participate in the companies justifies social ethics and applies to all areas of life in which they can all move around without restriction. The most important principles of inclusion, integration Seidler, Beliková, Dufeková (2013) are considered ethical principles. Concrete humanity, extraordinary, in which case the welfare of each other, and about the welfare of others, and unknown. Consequently, as stated in the Zimanová (2014) as editor, a new education portal that inclusion is a great chance for our education: "I think elementary school is the perfect place for children to learn that people are miscellaneous, have different talents, abilities and limitations, and yet together they know work can be friends, they know one another's help. This should be the task of the school of the future, not only to the children of the print the bounty of knowledge. Diversity should be considered as an asset, not a problem."

\section{Acceptance of students with special needs in the regular school environment}

As indicated above, the inclusion of a pupil into the main stream education does not guarantee its full commitment and acceptance of his person from the perspective of his peers. By Zbortekovej (2012) are integrating individuals in daily contact with their fellow students are confronted with loneliness, a sense of intact everolimus tablets, repeated expressions of indifference, or even decline. Lack of social integration may be seen as a serious problem, which can complicate the formation of the identity of the individual. Considering to the sociologic component inclusion it should be mentioned that at present, people with disabilities, to some extent, but rather it is a biggest community tolerated some form of integration, as a full inclusive trend (Leonhardt \& Lechta, eds., 2007). There is, therefore, in school and out of school, often referred to hidden discrimination and paradox: the inclusive education in turn establishes a (hid- 
den) social discrimination. Very pregnantne in this context, the implementation Požár (2006). Kročanová (2012) declares that the social interaction of individuals with intact everolimus tablets as a basic measure of the success of social integration, is related to age, gender, with differences of individuals, which are reflected in the social interindividual and language competence, level of skill, in a rabbit play in verbal skills, social contacts, experience in adapting to social rules and conventions intact, in the degree of adoption of methods applicable to peer games in frends group in the participation in the activities of a group of peers, in the sense of ourselves as part of the normal frends of the group. The ability of intact individuals participate in the inclusion of individuals with special needs impacts (ibid): social perception; social skills; the social experience of peers without handicaps; verbal abilities; motivation; intuition. These capabilities will be the effectiveness of the inclusion of individuals in a social group, or, in our terms, in the class.

It follows that, in the school environment between individuals and individuals with special needs intact everolimus tablets is in the process of social learning, where they have the opportunity to develop their social skills (Sollárová, 2008). Foreign studies draw attention to the social learning with an emphasis on the elements of emotional survival (Chien \& Harbin, 2012; Delate-O'Connor \& Farley, 2012), where schools and various organizations are looking for ways to effectively integrate social learning in the schools and their curricula. For example, the Child Trends focuses on the social skills that help individuals to manage their emotions, behavior, persevere toward your goals, change the value of learning to know work with others and to believe in their own accomplishments. The very emotional experience to interpersonal relationships, their formation and the way how bad interpersonal relationships and negative emotions threaten the physical and mental health of individuals.

The current modern world is full of conflicts, frustrácií, a burdens and risks. If education in the period of adolescence can't handle emotional personality, then a lack of emotional intelligence will issue an individual high risks (from depression or raw behavior to drug use, or eating disorders). Of that, of course, negative feelings, such as dissatisfaction, unhappiness, sadness, loneliness, the inability to experience pleasure, to suicide (Gajdošová \& Herenyiová, 2002). It is necessary to take into account the skills that are critical to the well-being of the individual and personal success for the harmony of the society. Emotional intelligence concerns the competences and skills, which substantially affect success in school, a man of social and intimate relationships. It consists of the seven qualities or abilities: awareness of self, self motivation, perseverance, control impulses, the regulation of mood, empathy, hope or optimism (Goleman, 1995). Referring to the above we want to compare the degree of social acceptance and integrated at the same time formulate the hypothesis of intact individuals and differences in the degree of emotional survival of individuals and the perspective of the individual to the collective of classes due to the intact individuals and individuals with special needs. 


\section{Research methods}

Questionnaire social acceptance (Juhás, 1990); (hereinafter DSA), the Slovak version released Psychodiagnostic in Bratislava, was established on the basis of a long-term examination of options for changes to the conduct of the individual in the group through active social learning. The questionnaire was developed in several stages. The number of items was gradually lowered by for maintaining the reliability of the questionnaire. Items in the final version of the questionnaire meeting the criteria of relative independence from the other items and meaningfulnessi in the examined issues. The questionnaire is composed of 4 variables - I. The Relationship of the individual to peers, II. The view of the individual to the team of the school class, III. Emotional survival of the individual in the school class, IV. Evaluation of the relationship of the family environment and the school. The value of the Cronbach alpha for individual variables are: I. variables 0.55 , II. variables 0.79 , III. variables 0.95 and IV. variables 0.92 , for a total for the whole questionnaire is 0.95 .

In the framework of the variable I. The Relationship of the individual to peers, is detected, the extent to which the respondent depends on the opinion of his classmates, as well as assessed satisfaction with how your individual's peers shall be weighted, whether frends with their classmates and outside the class and has a with them the same interests. Items are are heading off also on the popularity of the individual among peers, faith in the fact that his classmates will help, for his opinion on the inclusion of the in any of the groups in the class and in his opinion, to the fact that they have the best ones in the class who are kept in seclusion.

In variable II. The view of the individual to the team of class, is detected, to what extent would a person in another class, he felt better, that will be remembered for life in his class in a good way. Furthermore, the items are focused on determining the extent to which the individual is afraid to express their views in the class, the extent to which an individual gets along with his classmates well and to the appearance before the collective classes, to the good understanding of peers, on the seizure of their class, and last but not least, if an individual knows to share their achievements with classmates.

In variable III. Emotional survival of the individual in a school class, is the focus of the items on the individual towards those who do not want to make the most, for the application of even stricter methods to absence individual honest a friend in the class. Subsequently, we ascertained whether in the class will find also those peers who are to respondent behave neúprimne, when meeting with some classmates bothers him his clumsiness, in his class an individual is evaluated by marks and not by its properties. As well, if an individual believes that his classmates are better than he and ashamed when something fails, it is sensitive to various cues from the side of classmates.

In variable IV. Evaluation of the relationship of family and schoolclass, through the items we find peace individual fear, as a degree of concern that the parents are aware 
of it. As well, we want to find out the degree of volition of the individual, the parents were proud, he agrees to peace depend on.

\section{Research sample}

Representative research sample is made up of 398 adolescents aged 14 to 15 years, of which 194 boys ( $48.62 \%$ ) and girls (51.38\%). The reason for the choice of individuals 9 year is considered the most effective, because individuals are located in a transit period of go to school, where you can finally find their readiness for social adaptation to the new environment continued school. The research sample is the regular elementary school studnets in Slovakia in the Nitra, Bratislava, Banská Bystrica, Prešov, Trenčín, Trnava, Žilina and Košice region in the percentage distribution, which corresponds to the size of the population. The research sample meets the criteria of representativity according to approximation of Morgan \& Krejcie (1970).

Respondents were categorised according to integration into two groups:

- the first group consists of individuals without special needs, with the number of intakt individuals (81.40\%);

- the second group consists of individuals with special needs, integrating individuals with the number 74 (18.60\%).

\section{The results}

Statistical analyses were carried out in the IBM SPSS statistics 20 (Statistical Package for the Social Sciences) and STATA 13. For a description of the research data, we used the methods of descriptive statistics (Tomšik, 2016). To determine the normality of the distribution of the research data file has been used Kolmogorov-Smirnov (R) coefficient. Due to the fact that the data do not meet the criteria for further analysis of the commonality were elected by the nonparametric tests. The results of the statistical analysis are presented in tables 1 and 2 . 
Table 1

Descriptive statistics and research data normality

\begin{tabular}{|c|c|c|c|c|c|c|c|c|c|c|}
\hline Factor & Respondents & $\mathrm{N}$ & Min & Max & M & SD & SK & KU & $\mathbf{R}$ & p \\
\hline \multirow{2}{*}{$\begin{array}{l}\text { The Relationship } \\
\text { of the individual } \\
\text { to peers }\end{array}$} & without special needs & 324 & 10 & 32 & 20.99 & 3.311 & -0.160 & 0.304 & 1.384 & 0.043 \\
\hline & with special needs & 74 & 11 & 28 & 20.69 & 3.741 & -0.253 & -0.434 & 1.178 & 0.124 \\
\hline \multirow{2}{*}{$\begin{array}{l}\text { The view } \\
\text { of the individual } \\
\text { to the team class }\end{array}$} & without special needs & 324 & 11 & 35 & 22.48 & 3.271 & -0.206 & 1,306 & 1.773 & 0.004 \\
\hline & with special needs & 74 & 13 & 30 & 21.49 & 3.672 & 0.058 & -0.248 & 0.740 & 0.643 \\
\hline \multirow{2}{*}{$\begin{array}{l}\text { Emotional survival } \\
\text { of the individual } \\
\text { in a school class }\end{array}$} & without special needs & 324 & 10 & 37 & 20.06 & 4.650 & 0.811 & 0.788 & 2.283 & 0.000 \\
\hline & with special needs & 74 & 10 & 36 & 22.42 & 5.279 & 0.330 & 0.146 & 0.847 & 0.470 \\
\hline \multirow{2}{*}{$\begin{array}{l}\text { Evaluation } \\
\text { of the relationship } \\
\text { of family } \\
\text { and school class }\end{array}$} & without special needs & 324 & 7 & 18 & 12.47 & 2.131 & -0.113 & 0.019 & 1.937 & 0.001 \\
\hline & with special needs & 74 & 7 & 20 & 12.05 & 2.739 & 0.612 & 0.599 & 1.521 & 0.020 \\
\hline \multirow[t]{2}{*}{ Social acceptance } & without special needs & 324 & 51 & 104 & 76.00 & 8.514 & -0.112 & 0.582 & 1.267 & 0.081 \\
\hline & with special needs & 74 & 54 & 97 & 76.65 & 9.940 & -0.029 & -0.257 & 0.608 & 0.853 \\
\hline
\end{tabular}

* Note: $\mathrm{N}$ - number; $\mathrm{Min}$ - minimum score in the category concerned; $\mathrm{Max}$ - maximum score in the category concerned; $\mathrm{M}$ - average; SD - standard deviation; SK - skewness distribution; KU - kurtosis of a data set; $\mathrm{R}$ - Kolmogorov-Smirnov factor; $\mathrm{p}$ - Statistical significance Kolmogorov-Smirnov test for normality

The comparance research groups with regard to the type of respondents, we found a statistically significant difference at the level of the following variables: Emotional survival in the class of the DSA questionnaire individuals $(U=8451.000 ; p=0.000)$ and The view of the individual to the team class $(U=9837.000, p=0.015$. Significant differences were detected at the level of the entire DSA questionnaire. Beholding the values in Table 2, a greater degree of social acceptance of individuals with significant demonstrated without special needs for each variable obtained by difference, in addition to Emotional survival of the individual in a school class and Evaluation of the relationship of family and schoolclass. The view of the individual to the team class have reached about $M=0.99$ of a point above the average score (without special needs $M=22.48$; with special needs $M=21.49$ ), and in Emotional survival in the class about $M=2.36$ points (without special needs $M=20.06$; with special needs $M=22.44$ ). The overall average Social acceptance students without special needs have reached about $M=0.65$ points, compared with individuals (without special needs $M=76.65$; with special needs $M=76$ ). Given the differences between the variables view of The view of the individual to the team class $\left(r_{s}=0.213\right)$ and Emotional survival of the individual in a school class $\left(r_{s}=0.280\right)$ with regard to the type of respondents (without special needs and with special needs) confirmed the correlation analysis, where the relationship was detected on the levels 
of 0.01 . The Relationship of the individual to peers, Evaluation of the relationship of family and schoolclass and in the overall Social acceptance of significant difference was found.

Table 2

Comparison of the level of social acceptance due to students without special needs and iwith special needs

\begin{tabular}{|c|c|c|c|c|c|c|c|c|}
\hline Factor & Respondents & N & M & SD & SEM & df & U & $p$ \\
\hline \multirow{2}{*}{$\begin{array}{l}\text { The Relationship } \\
\text { of the individual to peers }\end{array}$} & without special needs & 324 & 20.99 & 3.311 & 3.311 & 394 & \multirow[t]{2}{*}{11519.000} & \multirow[t]{2}{*}{0.598} \\
\hline & with special needs & 74 & 20.69 & 3.741 & 3.741 & 394 & & \\
\hline \multirow{2}{*}{$\begin{array}{l}\text { The view of the individual } \\
\text { to the team class }\end{array}$} & without special needs & 324 & 22.48 & 3.271 & 3.271 & 394 & \multirow[t]{2}{*}{9837.000} & \multirow[t]{2}{*}{0.015} \\
\hline & with special needs & 74 & 21.49 & 3.672 & 3.672 & 394 & & \\
\hline \multirow{2}{*}{$\begin{array}{l}\text { Emotional survival of the } \\
\text { individual in a school class }\end{array}$} & without special needs & 324 & 20.06 & 4.650 & 4.650 & 394 & \multirow[t]{2}{*}{8451.500} & \multirow[t]{2}{*}{0.000} \\
\hline & with special needs & 74 & 22.42 & 5.279 & 5.279 & 394 & & \\
\hline \multirow{2}{*}{$\begin{array}{l}\text { Evaluation } \\
\text { of the relationship } \\
\text { of family and school class }\end{array}$} & without special needs & 324 & 12.47 & 2.131 & 2.131 & 394 & \multirow[t]{2}{*}{10274.500} & \multirow[t]{2}{*}{0.052} \\
\hline & with special needs & 74 & 12.05 & 2.739 & 2.739 & 394 & & \\
\hline \multirow[t]{2}{*}{ Social acceptance } & without special needs & 324 & 76.00 & 8.514 & 8.514 & 394 & \multirow[t]{2}{*}{11640.500} & \multirow[t]{2}{*}{0.697} \\
\hline & with special needs & 74 & 76.65 & 9.940 & 9.940 & 394 & & \\
\hline
\end{tabular}

* Note: $\mathrm{N}$ - number; $\mathrm{M}$ - average; SD - standard deviation; SEM - standard error of the mean; df - degrees of freedom; U-MannWhitney U test; $p$ - Statistical significance

\section{Discussion and conclusion}

As part of our research, we have focused on the degree of social acceptance of individuals under conditions of students without special needs and with special needs elementary school. School inclusion under based on Ainscow, Dyson \& Booth eds. (2006) in three dimensions that can be objectively and empirically examined: the presence of pupils in school; participation, active participation, degree of involvement; achievement. In this model, it is the participation of the parent concept of performance, academic success. Social relationships are creating identity, creating a network of us human interactions that inevitably we need for living together in any social group. In our study we found statistically significant differences The view of the individual to the team class $(U=9837.000, p=0.015)$ and Emotional survival of the individual in a school class $(U=8451.500, p=0.000)$. For the other variables, as well as in the overall Social acceptance has not been found between students without and with special needs. The results can be interpreted on the basis of facts, that the individuals are afraid to express their views more integrated in the class can be based on well with his classmates, as 
suggested by the difference in The Relationship of the individual to peers, but on the other hand, may have a problem with posing in front of the group and just does not like to share your success stories with classmates. This fact is confirmed by research, Frostad, Pijl \& Flem (2008), where it is stated that the integration of individuals are less popular and have a problem inside the relationships with their classmates. In the class it may exhibit poor communication or asertivitou by individuals with special needs.

Furthermore, we believe that these individuals do not want to be the center of attention, and for this reason I prefer to pull back, and their opinions, attitudes in the class are not reflected. A number of studies (Lörinczová, 2016; Scheepstra, eds., 1999; Soresi \& Nota, 2000) draw attention to individuals with special needs and a smaller degree of social skills, which are associated with a lack of making relations between the members of the group. With that is directly related to their emotional survival, which is an integral part of its identity. The sheer emotional survival is linked to its ability to manifest their opinion with others of the class and its ability to nehanbit ahead of classmates to say something. The same relates to his emotional intelligence and social skills that are directly linked studies Elliotta, Maleckie \& Demaray (2001); Kavala \& Forness (1996); Maleckie \& Elliotta (2002). The results repeatedly show that social skills are important for the successful socialization and academic success for all students, and the authors consider them to be important in the prevention of negative reviews from the other.

In conclusion, that the level of social acceptance because of the intact and integrated individuals achieved positive results, which suggest that the classification of individuals with special needs and inclusive education issues gradually leads to the coexistence of all individuals. On the other hand, some cracks and the possible problems from the perspective of individuals, we integrated the collective view of the class itself and its emotional survival. Therefore, we should focus on improving social skills, such as social skills training. The aim should be to develop and maintain contacts, relationships and friendships among peers, the Elimination of social exclusion, aggressive speeches or low sebaponatia. As the results show, that in the period of adolescence is a significant orientiert to support individuals I in a positive sense, to support his self-esteem, but also respect for other people. Social skills develop overall social and emotional intelligence of individuals, and thus support their healthy development (Lörinczová \& Žovinec, 2016). A number of studies (Elias, 1995; Jordan, eds., 1991), that such programs are based on the social and emotional aspects of indicating a solid basis of social skills aimed at helping individuals cope with the multiple challenges in your life. 


\section{References}

Anderliková, L. (2013). Cesta k inkluzi. Úvahy z praxe a pro praxi. Praha:TRITON.

Buysse, V., Goldman, D. B. \& Skinner, M. L. (2002). Setting effects on friendship formation among young children with and without disabilities. Exceptional Children, 68, 503-517.

Čerešník, M., \& Dolejš, M. eds. (2015). Spoločný projekt dvoch národov alebo podobnosti a rozdiely $v$ procese a výsledkoch výskumu zameraného na rizikové správanie a osobnostné rysy dospievajúcich na Slovensku a v Českej republike. PhD. Existence 2015 česko-slovenská psychologická konference (nejen) pro doktorandy a o doktorandech. Olomouc: Univerzita Palackého v Olomouci, 203-219.

Chien, N. \& Harbin, V. (2012). Encouraging the development of key life skills in elementary schoolage children: A literature review and recoomendations to the Tauck Family Foundation Washington. Child Trends.

Delate-O'Connor, B. L. \& Farley, CH., eds. (2012). Essential Self Management Skills: Summary of Research. Child Trends.

Elias, M. J. (1995). Primary prevention as health and social competence promotion. Journal of Primary Prevention, 1995, 16 (1), 5-24.

Elliott, S. N, Malecki, CH. K. \& Demaray, M. K. (2001). New Direcions in Social Skills Assessment and Intervention for Elementary and Middle School Students.

Frederickson, N., Dunsmuir, S., Lang, J. \& Monsen, J. J. (2004). Mainstream-special school inclusion partnerships: Pupil, parent and teacher perspectives. International Journal of Inclusive Education, 8, 37-57.

Fry, P. M. (1998) The development of personal meaning and wisdom in adolescence: A reexamination of moderating and consolidating factors and influences. The human quest for meaning. A handbook of psychological research and clinical applications.

Gajdošová, E. \& Herényiová, G. (2002). Škola rozvíjania emocionálnej inteligencie žiakov. 1. vyd. Bratislava: Príroda, $301 \mathrm{~s}$.

Goleman, D. (1995). Emoční inteligence. 2. vyd. Praha: Metafora, spol. s.r.o., 326.

Guralnick, M. J., Neville, B., Hammond, M. A., Connor, R. T. (2007). The friendships of young children with developmental delays. A longitudinal analysis. Journal of Applied Developmental Psychology, 28, 64-79.

Jordan, J., Kaplan, A. G., Miller, J. B., Stiver, I. P. \& Surrey, J. L. (1991). Women's growth in connection: Writings from the Stone Center. The Guilford Press, 310.

Jordan, C. H. et al. (2013). Responsive Low self-esteem: Low explicit self-esteem, implicit selfesteem, and reactions to performance outcomes. Journal of Social and Clinical Psychology, $32,7,703-732$.

Kavale, K. A. \& Forness, S. (1996). Social Skill Deficits and Learning Disabilities: A Meta-Analysis. Journal of Learning Disabilities.

Kročanová, L. (2012). Sociálne zručnosti detí so sluchovým postihnutím v bežnej materskej škole. Efeta, 2, XXII, 16-20.

Langmeier, J. \& Krejčiřová, D. (1998). Vývojová psychologie. Praha: Grada publishing.

Lechta, V. eds. (2010). Základy inkluzivní pedagogiky. Deti s postižením, narušením a ohrožením ve škole. Praha: Portál, $440 \mathrm{~s}$.

Leonhardt, A. \& Lechta, V., a kol. (2007). Inkluzívna pedagogika ako odbor, princíp a politikum, verzus jej realizácia. Efeta, 2, XVII, 2-4.

Lörinczová, E. (2016). Sociálny kapitál v diskurze edukačných koncepcií 21. storočia. MMK International Masaryk conference for ph.d. students and young researchers, VII, 724-732.

Lörinczová, E. \& Žovinec, E. (2016). Sociálne kompetencie žiakov v diskurze 21. storočia. Nitra: PF UKF v Nitre. 
Malecki, CH. K. \& Elliott, S. N. (2002). Children's Social Behaviors as Predictors of Academic Achievement: A longitudinal Analysis. School Psychology Quarterly, 17,1, 1-23.

Pavri, S. \& Luftig, S. (2000). The Social Face of Inclusive Education: Are Students with Lerning Disabilities Really Included in the Classroom?

Pijl, S. J., Frostad, P. \& Flem, A. (2008). The Social Position of Pupils with Special Needs in Regular Schools. Scandinavian Journal of Educational Research, 52, 4, 387-405.

Požár, L. (2006). Psychológia postihnutých (patopsychológia). Bratislava: Retaas.

Seidler, P., Beliková, V. \& Dufeková, A. (2013). [In]akosti v terciárnom vzdelávaní. Nitra: PF UKF v Nitre, 2013.

Scheepstra, A. J. M., Nakken, H. \& Pijl, S. J. (1999). Contacts with classmates: The social position of pupils with Down's syndrome in Dutch mainstream education. European Journal of Special Needs Education, 14, 212-220.

Sollárová, E. (2008). Socializácia. Sociálna psychológia. Bratislava: Polygrafické stredisko UK, 168-180.

Soresi, S. \& Nota, L. (2000). A social skill training for persons with Down's syndrome, European Psychologist, 5(1), 34-43.

Suchá, J. \& Dolejš, M. (2016). Agresivita, depresivita, sebehodnocení a impulzivita u českých adolescentů. Olomouc: Univerzita Palackého v Olomouci.

Tomšik, R. (2016). Štatistika v pedagogickom výskume: Aplikácia komparačných a korelačných metód pomocou programu Microsoft Excel. Nitra: UKF, $304 \mathrm{~s}$.

Zborteková, K. (2012). Sociálna inklúzia žiakov so sluchovým postihnutím a možnosti jej podpory. Výchovný aspekt inkluzívnej edukácie a jeho dimenzie, 2012, 260-272.

\section{Contact:}

Mgr. Eva Lörinczová

Deparment of education UKF in Nitra

Drážovska cesta 4, 94901 Nitra

Slovak Republic

Phone: +421376408 222

eva.lorinczova@ukf.sk 